OPEN ACCESS

Edited by:

Steffen Kolb,

Friedrich Schiller University Jena,

Germany

Reviewed by:

Christoph Mueller,

Justus Liebig University Giessen,

Germany

Richard Farrell,

University of Saskatchewan, Canada

*Correspondence: Henri M. P. Siljanen

henri.siljanen@uef.fi

tThese authors have contributed equally to this work.

Specialty section

This article was submitted to

Terrestrial Microbiology,

a section of the journal

Frontiers in Microbiology

Received: 30 April 2015

Accepted: 24 September 2015

Published: 14 October 2015

Citation:

Shvaleva A, Siljanen HMP, Correia A,

Costa e Silva F, Lamprecht RE,

Lobo-do-Vale R, Bicho C

Fangueiro $D$, Anderson M, Pereira JS,

Chaves MM, Cruz C

and Martikainen PJ (2015)

Environmental and microbial factors influencing methane and nitrous oxide

fluxes in Mediterranean cork oak woodlands: trees make a difference.

Front. Microbiol. 6:1104.

doi: 10.3389/fmicb.2015.01104

\section{Environmental and microbial factors influencing methane and nitrous oxide fluxes in Mediterranean cork oak woodlands: trees make a difference}

\author{
Alla Shvaleva ${ }^{1 t}$, Henri M. P. Siljanen ${ }^{2 *}$, Alexandra Correia $^{3}$, Filipe Costa e Silva ${ }^{3}$, \\ Richard E. Lamprecht ${ }^{2}$, Raquel Lobo-do-Vale ${ }^{3}$, Catarina Bicho' ${ }^{1}$, David Fangueiro ${ }^{4}$, \\ Margaret Anderson ${ }^{5}$, João S. Pereira ${ }^{3}$, Maria M. Chaves ${ }^{1}$, Cristina Cruz $^{6}$ and \\ Pertti J. Martikainen ${ }^{2}$
}

\begin{abstract}
${ }^{1}$ Instituto de Tecnologia Química e Biológica, Universidade Nova de Lisboa, Oeiras, Portugal, ${ }^{2}$ Department of Environmental Science, University of Eastern Finland, Kuopio, Finland, ${ }^{3}$ Centro de Estudos Florestais, Instituto Superior de Agronomia, Universidade de Lisboa, Lisboa, Portugal, ${ }^{4}$ Landscape, Environment, Agriculture and Food, Instituto Superior de Agronomia, Universidade de Lisboa, Lisboa, Portugal, ${ }^{5}$ Centre for Ecology and Hydrology, Penicuik, UK, ${ }^{6}$ Centre for Ecology Evolution and Environmental Changes, Faculdade de Ciências, Universidade de Lisboa, Lisboa, Portugal
\end{abstract}

Cork oak woodlands (montado) are agroforestry systems distributed all over the Mediterranean basin with a very important social, economic and ecological value. A generalized cork oak decline has been occurring in the last decades jeopardizing its future sustainability. It is unknown how loss of tree cover affects microbial processes that are consuming greenhouse gases in the montado ecosystem. The study was conducted under two different conditions in the natural understory of a cork oak woodland in center Portugal: under tree canopy (UC) and open areas without trees (OA). Fluxes of methane and nitrous oxide were measured with a static chamber technique. In order to quantify methanotrophs and bacteria capable of nitrous oxide consumption, we used quantitative real-time PCR targeting the pmoA and nos $Z$ genes encoding the subunit of particulate methane mono-oxygenase and catalytic subunit of the nitrous oxide reductase, respectively. A significant seasonal effect was found on $\mathrm{CH}_{4}$ and $\mathrm{N}_{2} \mathrm{O}$ fluxes and pmoA and nos $Z$ gene abundance. Tree cover had no effect on methane fluxes; conversely, whereas the UC plots were net emitters of nitrous oxide, the loss of tree cover resulted in a shift in the emission pattern such that the OA plots were a net sink for nitrous oxide. In a seasonal time scale, the UC had higher gene abundance of Type I methanotrophs. Methane flux correlated negatively with abundance of Type I methanotrophs in the UC plots. Nitrous oxide flux correlated negatively with nos $Z$ gene abundance at the OA plots in contrast to that at the UC plots. In the UC soil, soil organic matter had a positive effect on soil extracellular enzyme activities, which correlated positively with the $\mathrm{N}_{2} \mathrm{O}$ flux. Our results demonstrated that tree cover affects soil properties, key enzyme activities and abundance of microorganisms and, consequently net $\mathrm{CH}_{4}$ and $\mathrm{N}_{2} \mathrm{O}$ exchange.

Keywords: Mediterranean, oak woodland, methane, nitrous oxide, enzymes, pmoA, nosZ 


\section{INTRODUCTION}

Carbon dioxide $\left(\mathrm{CO}_{2}\right)$,methane $\left(\mathrm{CH}_{4}\right)$, and nitrous oxide $\left(\mathrm{N}_{2} \mathrm{O}\right)$ are the most important greenhouse gasses (GHG) responsible for global warming. Methane and nitrous oxide contribute 17 and $6 \%$ to total global warming (Myhre et al., 2013), respectively. Climate change scenarios for the Iberian Peninsula suggest drier conditions (an average decrease of $20 \%$ in precipitation during both winter and summer) and an increase of $40 \%$ of the inter-annual variability in the dry period (Meehl and Tebaldi, 2004; Lionello, 2007). This will modify hydrological regimes in Mediterranean-type ecosystems, including the soil's wet-dry cycles. In the last decades, a decline in cork oak (Quercus sp.) has been observed (AFN, 2010) with an increase in tree vulnerability to abiotic and biotic stresses (Garcia-Herrera et al., 2007). Severe and recurrent droughts, as well as intensified wetdry cycles due to changing climate will alter physical and chemical soil properties, which in turn will affect soil microbiological communities and their activity. Fluctuations of wet-dry cycles have been suggested to have a mechanistic interaction on denitrification through oxygen mediated derepression kinetics, which can contribute to peak $\mathrm{N}_{2} \mathrm{O}$ emissions (Smith and Tiedje, 1979; Betlach and Tiedje, 1981). Moreover, soil moisture can alter the induction time of $\mathrm{CH}_{4}$ oxidation in forest soils (Bender and Conrad, 1995). However, relatively little is known about the influence of wet-dry cycles on the fluxes of greenhouse gasses (GHGs) such as $\mathrm{CH}_{4}$ and $\mathrm{N}_{2} \mathrm{O}$ in Mediterranean oak forests.

Methane consumption in upland soils is mainly driven by soil methanotrophs, which are unique in their ability to use $\mathrm{CH}_{4}$ as carbon and energy sources (Hanson and Hanson, 1996). Methanotrophs are traditionally classified into Type I (aerobic Gammaproteobacteria) and Type II (aerobic Alphaproteobacteria) groups (Hanson and Hanson, 1996). Methanotrophs have the functional gene $p m o A$, which encodes a subunit of particulate methane monooxygenase (pMMO). This gene exists in all methanotrophs with the exceptions of Methylocella sp. and Methyloferula sp., which have soluble MMO (sMMO; Theisen et al., 2005; Vorobév et al., 2011). Therefore, MMO genes are widely used as a biological marker in molecular ecological studies of methanotrophs (McDonald et al., 2008). Methanotrophs are widely distributed in various environments: such as paddy soils (Bodelier et al., 2000), upland forest soils (Knief et al., 2006; Lau et al., 2007; Mohanty et al., 2007; Kolb, 2009), landfill soils, wetlands (Einola et al., 2007; Siljanen et al., 2011), alpine grassland soils (Abell et al., 2009), and extreme thermoacidophilic environments (Pol et al., 2007; Islam et al., 2008). Soil moisture is important for induction of $\mathrm{CH}_{4}$ oxidation and regulation of $\mathrm{CH}_{4}$ uptake in soil (Bender and Conrad, 1995; Shrestha et al., 2012). However, methanotrophs are poorly known in temporally dry Mediterranean soils and little is known about how wet-dry cycles influence methanotroph activity and abundance under different vegetation covers (Castaldi and Fierro, 2005; Castaldi et al., 2007; Shvaleva et al., 2014).

The main biological sources of nitrous oxide in soil are nitrification and denitrification processes catalyzed by archaea, bacteria, and fungi (Braker and Conrad, 2011; Thomson et al.,
2012; Stieglmaier et al., 2014). Although archaeal nitrifiers and fungal denitrifiers have the ability to produce $\mathrm{NO}$ and $\mathrm{N}_{2} \mathrm{O}$, they lack the capacity for complete $\mathrm{N}_{2} \mathrm{O}$ reduction to $\mathrm{N}_{2}$ (Shoun et al., 1992; Kim et al., 2009; Bartossek et al., 2010; Walker et al., 2010; Stieglmaier et al., 2014). Production of $\mathrm{N}_{2} \mathrm{O}$ in forest soils depends on soil characteristics [e.g., moisture, temperature, aeration, $\mathrm{pH}$, soil organic matter (SOM), nitrogen availability] as well as tree species composition (Butterbach-Bahl and Papen, 2002; Skiba et al., 2009; Weslien et al., 2009).

Biological consumption of nitrous oxide in soil is catalyzed by nitrous oxide reductase (NOR) of denitrifying bacteria, which reduces $\mathrm{N}_{2} \mathrm{O}$ to $\mathrm{N}_{2}$. Whether soil acts as a sink or a source of nitrous oxide depends on the balance of $\mathrm{N}_{2} \mathrm{O}$ production (nitrification and denitrification) and abundance and activity of denitrifying bacteria carrying NOR. In recent years, the nos $Z$ gene, which encodes the catalytic subunit of NOR, has been used as a common molecular marker for analysis of abundance and diversity of denitrifiers capable of $\mathrm{N}_{2} \mathrm{O}$ consumption in soil (Rich et al., 2003; Horn et al., 2006). Novel clade of denitrifiers, recognized as atypical nos $Z$ (Sanford et al., 2012) or nos $Z$ clade II (nosZ-II; Jones et al., 2013), have been recently found to dominate over previously known denitrifiers (Jones et al., 2013). These novel nosZ-II carrying denitrifiers have been suggested to contribute significantly to $\mathrm{N}_{2} \mathrm{O}$ consumption/sink activities, since these genes can be correlated with an $\mathrm{N}_{2} \mathrm{O}$ sink (Jones et al., 2014) and a major part of the genomes of these organisms lack genes for $\mathrm{N}_{2} \mathrm{O}$ production (Sanford et al., 2012). However, their respective contribution to the consumption of atmospheric $\mathrm{N}_{2} \mathrm{O}$ is yet to be clearly established.

The heterotrophic soil microbial community is largely responsible for the mineralization of SOM (Bardgett et al., 2002) and availability of carbon and nitrogen regulating microbial processes behind the $\mathrm{CH}_{4}$ and $\mathrm{N}_{2} \mathrm{O}$ fluxes. Soil extracellular enzymes play a critical role in SOM decomposition regulating both carbon storage and nutrient supply (Burns and Dick, 2002). Human disturbance and changes in climate can substantially alter the availability of soluble carbon and nitrogen in soil (Nermani et al., 2003). The dry periods represent a significant physiological stress for soil microbial communities (Fierer et al., 2003; Jensen et al., 2003; Gordon et al., 2008; Kardol et al., 2011) and their extracellular enzyme activities (EEAs; Sardans and Penuelas, 2012), which results in reduced SOM turnover and soil nutrient availability (Schmidt et al., 2004; Allison and Treseder, 2008). This can then affect the specific microbial processes driving $\mathrm{CH}_{4}$ and $\mathrm{N}_{2} \mathrm{O}$ dynamics.

Previously, we showed that oak trees influence soil properties by increasing the input of litter fall (increase in SOM) which together with changes in soil water content (SWC) can affect net $\mathrm{CH}_{4}$ and $\mathrm{N}_{2} \mathrm{O}$ exchange in Mediterranean type ecosystems (Shvaleva et al., 2014). We hypothesize here that trees may affect soil microclimate and prolong influences of wet-dry cycles due to decreased evaporation rates and water uptake from deeper soil layers, which may in turn affect soil extracellular enzymatic activities and therefore have an impact on the functioning of methanotrophs and denitrifying bacteria. The specific hypotheses were: (1) plant cover (cork oak trees) has an effect on abundance of methanotrophs and $\mathrm{N}_{2} \mathrm{O}$ consuming microbes and moreover 
on $\mathrm{N}_{2} \mathrm{O}$ and $\mathrm{CH}_{4}$ fluxes, and (2) in addition to the effect of plant cover, seasonal variation in weather (temperature and precipitation) have an effect on the abundance of methanotrophs and $\mathrm{N}_{2} \mathrm{O}$ consuming bacteria.

\section{MATERIALS AND METHODS}

\section{Site Description}

The experimental site was located in Herdade da Machoqueira do Grou $\left(39^{\circ} 08^{\prime} 18.29^{\prime \prime} \mathrm{N}, 8^{\circ} 19^{\prime} 57.68^{\prime \prime} \mathrm{W}\right), 30 \mathrm{~km}$ northeast of Coruche, Portugal. The region has a typical Mediterranean climate with hot and dry summers, and moderately cold and mild wet winters. Long-term average meteorological data for this area show that more than $80 \%$ of annual precipitation $(c a 669 \mathrm{~mm}$ ) occurs between October and May and mean annual temperature is $\sim 15.9^{\circ} \mathrm{C}$ (Inst. of Meteorology, Lisbon). The study site is a typical evergreen cork oak open woodland with tree stand age of 50 years and a density of 177 trees $h^{-1}$. The site is certified as montado and is part of a long-term ecological research project (LTER-Montado), which guarantees sustainable management. The natural understory consists of Mediterranean shrub species such as Cistus salviifolius L., Cistus crispus L., Lavandula stoechas L., and Ulex spp. and grasses. Two different areas (ca $25 \mathrm{~m}^{2}$ each) were used to study $\mathrm{CH}_{4}$ and $\mathrm{N}_{2} \mathrm{O}$ fluxes, soil properties and abundance of soil microbial communities. These areas were established in the natural understory: under projection of tree crowns (under canopy, hereafter named as UC area); and in large OAs not under projection of tree crowns (hereafter named as OA area). The soil is Cambisol (FAO). The distance between study areas was ca $100 \mathrm{~m}$. Standard meteorological data for rainfall (ARG100, Environmental Measurements Ltd., Gateshead, UK), air humidity and temperature (CS215, Campbell, Inc., Logan, UT, USA) were collected over the study period at $30 \mathrm{~min}$ intervals and stored using a data logger (CR10X, Campbell Scientific, Inc., Logan, UT, USA).

\section{Soil Sampling and Temperature}

Samples used for determination of seasonal heterogeneity of soil chemical and physical properties and abundance of microbial communities capable of $\mathrm{CH}_{4}$ and $\mathrm{N}_{2} \mathrm{O}$ consumption were taken in 2011, May 23rd (end of spring rains), August 31st (dry extreme conditions), October 26th (after the first autumn rain event since August), November 9th (wet extreme) and December 15th (stabilized wet conditions) from triplicated study plots in the UC and OA areas. Soil cores (height $20 \mathrm{~cm}$, diameter $2 \mathrm{~cm}$ ) were collected from four randomly selected points in the UC and OA areas. For EEA determination, soil samples were additionally taken on July 6th, October 20th, and October 27 th in order to increase the power of principal component analysis (PCA). Soil samples were packed in plastic bags and transported to the laboratory in an ice-cooled box. Soil samples for molecular biological analyses were immediately stored at $-80^{\circ} \mathrm{C}$. Soil temperature at $5 \mathrm{~cm}$ depth was measured near to soil gas flux collars by using a digital thermometer. The sample collection was always performed between 09:00 and 13:00 h.

\section{Soil Chemical Characteristics (C, N, P, SOM, pH, and Electrical Conductivity)}

Soil samples for chemical analyses were first sieved $(1 \mathrm{~mm}$ mesh) and then separated into three parts. One part was used to determine gravimetric SWC (\%) by assessing weight loss after drying at $105^{\circ} \mathrm{C}$ for $24 \mathrm{~h}$. A second part was used to determine nitrate $\left(\mathrm{NO}_{3}{ }^{-}\right)$and ammonium $\left(\mathrm{NH}_{4}{ }^{+}\right)$concentrations by spectrophotometry as described in Fangueiro et al. (2008). The third part of the soil samples was air-dried and analyzed for total soil organic carbon according to Nelson and Sommers (1996) using an Infrared Detection Promacs TOC Analyser (Skalar, Netherlands). SOM content was determined from the soil carbon data using the conventional Van Bemmelen factor of 1.72, i.e., SOM $(\%)=$ soil carbon $(\%) \times 1.72$ (Nelson and Sommers, 1996). Total nitrogen in the soil was quantified by the Kjeldahl method (Horneck and Miller, 1998), and total phosphorous was determined by the Egner-Rhiem method (Carreira and Lajtha, 1997) using molecular absorption spectrophotometry (Hitachi 2000, Tokyo, Japan). Soil pH was determined in a soil-water suspension $(1: 10, \mathrm{w} / \mathrm{v})$ with a selective electrode (Micro pH 2001, Criston). Soil electrical conductivity (EC) was measured in a soil-water suspension (1:5, w/v), as described in Fangueiro et al. (2008).

\section{Enzyme Assays}

Soil samples preserved at $4-6^{\circ} \mathrm{C}$ were used to determine EEA applying photometric and fluorometric micro-plate assays described by Pritsch et al. (2011). Seven EEA were measured, i.e., 1.4- $\beta$-xylosidase (Xyl, EC: 3.2.1.37) in presence of MU-xyloside; $\beta$-glucuronidase (Glr, EC: 3.2.1.31) in presence of $\mathrm{MU}$ glucoronide; $1,4-\beta$-cellobiosidase (Cel, EC: 3.2 .1 .91 ) in presence of MU cellobioydrofuran; $N$-acetyl- $\beta$-D-glucosaminidase (Nag, EC: 3.2.1.14) in presence of MU-N-acetylglucosamine; $\beta$-glycosidase (Gls, 3.2.1.21) in presence of MU- $\beta$-glycoside, acid phosphatase (Pho, EC: 3.1.3.2) and laccase (Lac, EC: 1.10.3.2) in presence of 2,2'-azino-bis(3-ethylbenzothiazoline-6-sulphonic acid) ABTS. The main functions of these enzymes are listed in Supplementary Table S2.

\section{Tree Litter Fall and Root Density}

Tree litter fall was determined as described in Shvaleva et al. (2014) with 16 litter baskets placed in two transects across the site with periodic sampling throughout 2011. Root density (dry mass $\mathrm{m}^{-2}$ ) of soil was determined from triplicate soil samples of $0.2 \mathrm{~m} \times 0.2 \mathrm{~m} \times 0.2 \mathrm{~m}$, collected in October 2011. In the laboratory, roots were separated from the soil, washed, and dried at $65^{\circ} \mathrm{C}$ for $48 \mathrm{~h}$.

\section{Soil GHG Flux Measurement}

Soil-atmosphere net GHG fluxes were measured from six cylindrical collars randomly installed in both UC and OA areas (three replicated study plots per area/treatment). Cylinder collars (polypropylene cylinders, Technical University of Lisbon, Portugal) of $0.3 \mathrm{~m}$ diameter were placed at $0.1 \mathrm{~m}$ depth into the soil, giving a headspace volume of $0.010( \pm 0.001) \mathrm{m}^{3}$. The collars were closed with a stainless-steel lid fitted with sample ports 
( $0.006 \mathrm{~m}$ diameter), which could be closed and opened by lock valves. The distance between replicates in UC and OA areas was ca. $5 \mathrm{~m}$. Flux measurements were done as described in Shvaleva et al. (2014). The chamber was closed at time 0 , and samples were taken immediately, at $30 \mathrm{~min}$ and after $60 \mathrm{~min}$. Samples of $100 \mathrm{~mL}$ were taken from the chambers using a plastic syringe and stored in $20 \mathrm{~mL}$ gas vials stopped with butyl rubber septa. Nitrous oxide and $\mathrm{CH}_{4}$ concentrations were analyzed at $\mathrm{CEH}$ (Edinburgh, UK) by a gas chromatograph (GC, HP5890 Series II, Hewlett Packard, Agilent Technologies UK Ltd., Stockport, UK) fitted with an electron capture detector (ECD) and a flame ionization detector (FID) for $\mathrm{N}_{2} \mathrm{O}$ and $\mathrm{CH}_{4}$ analysis, respectively. The flux was calculated based on the slope of a linear regression fitted on data over the measurement time. Calibration of GC was performed with four standard gasses (concentration range: 0.205-1.008 ppm for $\mathrm{N}_{2} \mathrm{O}$ and 1.26-100.9 ppm for $\mathrm{CH}_{4}$ ). GC precision was calculated based on standard gas measurements ( $N=2-6$, depending on number of samples in the GC run). Precision of $\mathrm{N}_{2} \mathrm{O}$ and $\mathrm{CH}_{4}$ standards for each four standard gas concentration of all GC runs was $\pm 7 \mathrm{ppb}(N=44)$ for $\mathrm{N}_{2} \mathrm{O}$ and $\pm 70 \mathrm{ppb}(\mathrm{N}=44)$ for $\mathrm{CH}_{4}$. Minimum detectable fluxes based on precision of GC were $0.94 \mu \mathrm{g} \mathrm{N}_{2} \mathrm{O}-\mathrm{N} \mathrm{m}^{-2} \mathrm{~h}^{-1}$ for $\mathrm{N}_{2} \mathrm{O}$ fluxes and, $11.11 \mu \mathrm{g} \mathrm{CH}_{4}-\mathrm{C} \mathrm{m}^{-2} \mathrm{~h}^{-1}$ for $\mathrm{CH}_{4}$ fluxes with $60 \mathrm{~min}$ timescale in chamber volume of $0.010 \mathrm{~m}^{3}$ and at $20^{\circ} \mathrm{C}$ temperature. Discarding these small fluxes (production or consumption) below minimum detectable fluxes would have lead on average to 220 and $53 \%$ overestimation of $\mathrm{CH}_{4}$ and $\mathrm{N}_{2} \mathrm{O}$ fluxes, respectively. Nitrous oxide and $\mathrm{CH}_{4}$ fluxes were compared to each other by calculating $\mathrm{CO}_{2}$-equivalent values for both $\mathrm{CH}_{4}$ and $\mathrm{N}_{2} \mathrm{O}$ fluxes for making overall comparison of both processes easier. This comparison was made based on radiative forcing of these gasses over 100 years time horizon, factor for $\mathrm{CH}_{4}$ was 34 and 298 for $\mathrm{N}_{2} \mathrm{O}$ (Myhre et al., 2013).

\section{Soil DNA Extraction and Purification}

Freeze-dried mortar-homogenized $100 \mathrm{mg}$ soil (stored at $-80^{\circ} \mathrm{C}$ ) was used for DNA extraction as described in Siljanen et al. (2011) with slight modification. In brief, after phenol/chloroform/isoamylalcohol extraction, DNA was brownish and therefore it was further purified with PEG6000/ $\mathrm{NaCl}$ precipitation as previously described by Griffiths et al. (2000). After purification DNA was eluted with $50 \mu \mathrm{l}$ TE-buffer (Tris-Cl $10 \mathrm{mM}$, EDTA $1 \mathrm{mM}, \mathrm{pH}$ 8.0) and stored at $-20^{\circ} \mathrm{C}$.

\section{Quantitative PCR}

Presence of PCR inhibiting substances were analyzed by dilution series of extracted DNA with Bacterial 16S rRNA quantitative PCR. It was shown that PCR reaction was not inhibited by undiluted DNA thus samples were used in further analyses. Supplementary Table S3 shows the complete list of primers and conditions used for quantification of microbial communities running $\mathrm{CH}_{4}$ and $\mathrm{N}_{2} \mathrm{O}$ consumption. Primer combination A189q (5'-GGNGACTGGGACTTCTGG-3') and Mb601 (5'ACRTAGTGGTAACCTTGYAA-3') targeting $p m o A$ gene of Type Ia methanotrophs produced PCR product successfully. For analysis of nitrous oxide consuming bacteria primers targeting nosZ genes, nosZ2F ( $5^{\prime}$-CGCRACGGCAASAAGGTSMSSGT$\left.3^{\prime}\right)$ and nosZ2R ( $5^{\prime}$-CAKRTGCAKSGCRTGGCAGAA-3'; Henry et al., 2006) primers were used. Both genes were amplified with previously published cycling conditions with Bio-Rad iCycler iQ (Kolb et al., 2003; Henry et al., 2006). Reaction mixtures contained 2x Maxima SYBR Green master mix (Thermo Scientific) and $1 \mu \mathrm{M}$ of each primer. The quantification of $p m o A$ genes was done with cloned fragment of $p m o A$ gene according to Siljanen et al. (2011). For quantification of nos $Z$ gene genomic DNA of Pseudomonas aeruginosa was used. Quantification of both genes was based on a standard curve using 10-fold diluted positive control. Detection limits of qPCR assays were determined from dilution series of positive-control DNA (for pmo $A 10^{8}$ to $10^{1}$ and for nos $Z 10^{6}$ to $10^{1}$ ) target molecules per reaction. A minimum sensitivity of $10^{1}$ to $10^{2}$ target molecules per reaction for each assay was achieved. Amplified PCR products were confirmed by sequencing small clone libraries for both assays.

\section{Statistical Analyses}

A mixed-effect model was used to evaluate the difference of measured variables between UC and OA areas over the timescale studied as previously described in Siljanen et al. (2012). When the data were not normally distributed, they were either square root transformed prior to analysis or non-parametric tests were carried out by performing a comparison on ranks and using Dunn's test was used for post hoc pairwise comparisons. The Pearson Product Moment Correlation coefficient was used to display the strength of the association between pairs of variables. All statistical relationships were considered significant at $P<0.05$. Statistical analyses were carried out using SigmaStat (SigmaPlot for windows V 11, Dundas Software, Germany), SPSS 17.0 (SPSS, Inc., USA) and R statistical program (R Core Team, 2013).

\section{RESULTS}

\section{Soil Properties}

In 2011 the total annual precipitation was $883 \mathrm{~mm}$ and the average air temperature $15.5^{\circ} \mathrm{C}$. August was an extremely dry (only $8 \mathrm{~mm}$ precipitation) and warm month (Supplementary Table S1). In October, mean air temperature $\left(21^{\circ} \mathrm{C}\right)$ was higher than the long-term (1970-2000) average $\left(16^{\circ} \mathrm{C}\right)$. Summer conditions extended until mid-October (first rain events occurred on DOY 296 - October 22nd). SWC at $10 \mathrm{~cm}$ depth ranged from 2 to $19.5 \%$ in the UC and from 0.6 to $16 \%$ in the OA (Figure 1A). The UC soil was significantly wetter $(P<0.001)$ than the OA soil in May, August, and November (Table 1). Soil temperature recorded in the upper $0.05 \mathrm{~m}$ varied between 13.7 and $23^{\circ} \mathrm{C}$ in the UC and between 12.7 and $27.9^{\circ} \mathrm{C}$ in the OA. The UC had lower soil temperatures than in the OA in May and August, but in December the reverse was true (Table 1).

SOM content in May, August, and December was higher in the UC than in the OA (Table 1). The presence of trees in the UC provided twice the input of dry mass $\mathrm{m}^{-2}$ (litter fall) compared 


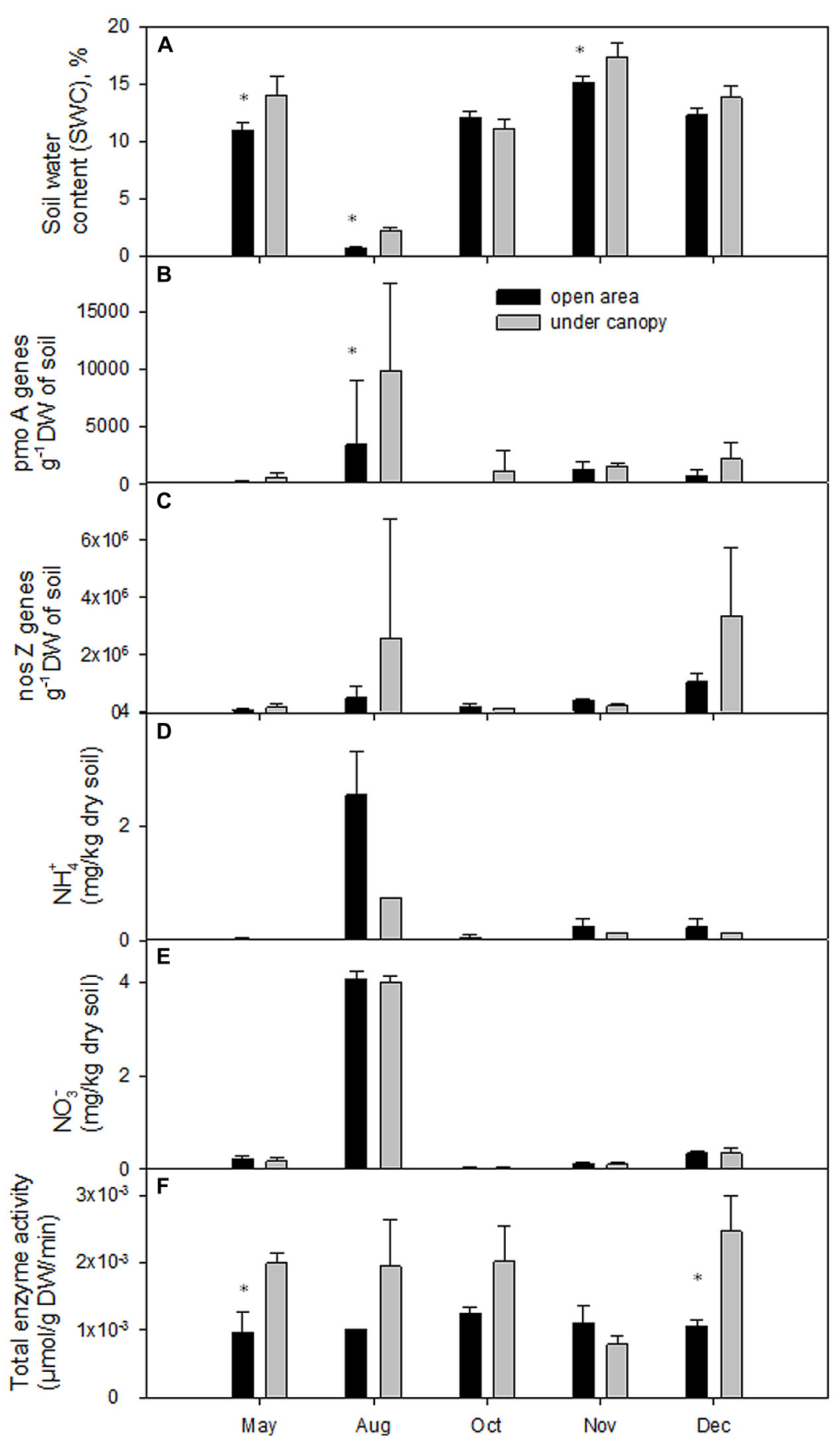

FIGURE 1 | (A) Soil water content (SWC,\%), (B) pmoA gene abundance, (C) nosZ gene abundance, (D) soil $\mathrm{NH}_{4}{ }^{+}-\mathrm{N}$ concentration, (E) soil $\mathrm{NO}_{3}{ }^{-}-\mathrm{N}$ concentration, and $\mathbf{( F )}$ total activities of studied enzymes in the $0-20 \mathrm{~cm}$ soil layers of the study areas. Statistical significance $(P<0.05)$ is shown with asterisk.

to the OA (290 $\mathrm{g} \mathrm{DW} \mathrm{m}^{-2} \mathrm{y}^{-1}$ vs. $140 \mathrm{~g} \mathrm{DW} \mathrm{m}^{-2} \mathrm{y}^{-1}$ ) and more than twice the root density in the OA $(693 \pm 70 \mathrm{~g} \mathrm{DW}$ $\mathrm{m}^{-2} \mathrm{y}^{-1}$ vs. $314 \pm 58 \mathrm{~g} \mathrm{DW} \mathrm{m}^{-2} \mathrm{y}^{-1}$ ). Similarly to SOM, soil electrical conductivity in UC was higher in May, August, and December compared to that in the OA (Table 1). No significant differences in soil $\mathrm{pH}$ between UC and OA areas were found.
Soil total organic carbon and phosphorus $\left(\mathrm{P}_{2} \mathrm{O}_{5}\right)$ contents were variable and ranged from 1 to $5.8 \%$, and from 4.2 to $30.6 \mathrm{mg} \mathrm{kg}^{-1}$ DW, respectively; these contents in the UC area were significantly higher in May, August, and December (Table 1). No differences in total soil $\mathrm{N}$, and content of $\mathrm{NO}_{3}{ }^{-}-\mathrm{N}$ and $\mathrm{NH}_{4}{ }^{+}-\mathrm{N}$ content between the UC and OA were observed. 
TABLE 1 | Statistical significance of the effect of site [under canopy (UC) vs. $\mathrm{OA}$ as determined by pair wise comparison] on different soil related parameters: SWC (\%), soil temperature, $\mathrm{pH}$, soil organic matter (SOM), soil $\mathrm{C} / \mathrm{N}$ ratio, carbon $(\mathrm{C})$, nitrogen $(\mathrm{N})$, phosphors $\left(\mathrm{P}_{2} \mathrm{O}_{5}\right)$, electrical conductivity (EC), $\mathrm{NH}_{4}{ }^{+}$- content, $\mathrm{NO}_{3}{ }^{-}$- content, B-glycosidase (GIs), cellobiosidase (Cel), glucuronidase (Glr), glucosaminidase (Nag), phosphatase (Pho), xylosidase (Xyl), total enzymes, pmoA gene, nosZ gene during the study period.

\begin{tabular}{|c|c|c|c|c|c|}
\hline $\begin{array}{l}\text { Parameters } \\
\text { significance of } \\
\text { effect (site/time) }\end{array}$ & May & August & October & November & December \\
\hline SWC $* * * / * * *$ & $+* * *$ & $+* * *$ & ns & $+^{*}$ & ns \\
\hline $\begin{array}{l}\text { Soil temperature } \\
* / * * *\end{array}$ & $-{ }^{* * *}$ & $-{ }^{* * *}$ & ns & ns & $+{ }^{*}$ \\
\hline $\mathrm{pH}$ & ns & ns & ns & ns & ns \\
\hline $\mathrm{SOM}^{* * *} / * * *$ & $+* *$ & $+* *$ & ns & ns & $+{ }^{*}$ \\
\hline $\mathrm{C} / \mathrm{N}$ & ns & ns & ns & ns & ns \\
\hline $\mathrm{C} * / * *$ & $+* *$ & $+^{*}$ & ns & ns & $+{ }^{*}$ \\
\hline $\mathrm{N}^{* *} /-$ & ns & ns & ns & ns & $+*$ \\
\hline $\mathrm{P}_{2} \mathrm{O}_{5} * /-$ & $+{ }^{*}$ & $+{ }^{*}$ & ns & ns & $+{ }^{*}$ \\
\hline $\mathrm{EC} * / * * *$ & $+* *$ & $+* *$ & ns & ns & $+{ }^{*}$ \\
\hline $\mathrm{NH}_{4}+-/ * * *$ & ns & ns & ns & ns & ns \\
\hline $\mathrm{NO}_{3}{ }^{-}-/ * * *$ & ns & ns & ns & ns & ns \\
\hline Gls & ns & ns & ns & ns & ns \\
\hline Cel & $+^{*}$ & ns & ns & ns & ns \\
\hline Glr $-/ * *$ & $+^{*}$ & ns & ns & ns & ns \\
\hline Nag & ns & ns & ns & ns & $+* *$ \\
\hline Pho */* & $+{ }^{*}$ & $-{ }^{*}$ & ns & ns & $+* *$ \\
\hline Xyl -/* & $+* *$ & ns & ns & $-* *$ & ns \\
\hline Total enzymes & $+* *$ & ns & ns & ns & $+* *$ \\
\hline pmoA gene $-/ * *$ & ns & $+{ }^{*}$ & ns & ns & ns \\
\hline nosZ gene $-/^{*}$ & ns & ns & ns & ns & ns \\
\hline $\mathrm{CH}_{4}$ flux $-/^{*}$ & ns & ns & $+{ }^{*}$ & ns & $-{ }^{*}$ \\
\hline $\mathrm{N}_{2} \mathrm{O}$ flux $* / *$ & ns & ns & ns & ns & $+*$ \\
\hline \multicolumn{6}{|c|}{$\begin{array}{l}\text { Symbols: } *, * * * * \text { represent statistical significance at } P<0.05, P<0.01 \text {, and } \\
P<0.001 \text {, respectively; and ns is not significant at } P=0.05 \text {, the "tree effect" } \\
\text { is shown with }+ \text {, if under canopy have higher value than open area, and - shows } \\
\text { if the under canopy has lower value than the open area. Statistically significant } \\
\text { differences of sites and timepoints across all sampling dates are marked with } \\
\text { asterisk beside parameter name. }\end{array}$} \\
\hline
\end{tabular}

\section{Quantification of pmoA and nosZ Genes}

The methanotrophic pmoA gene abundance was detected throughout the study period in the $\mathrm{UC}$ and $\mathrm{OA}$ areas and ranged from $3 \times 10^{2}$ to $16 \times 10^{3}$ pmoA genes $\mathrm{g}^{-1} \mathrm{DW}$ and from $8 \times 10^{1} \mathrm{pmoA}$ genes $\mathrm{g}^{-1} \mathrm{DW}$ to $10 \times 10^{3} \mathrm{pmoA}$ genes $\mathrm{g}^{-1} \mathrm{DW}$, respectively. In the UC site Type Ia $p m o A$ gene copy numbers were more than 10 times higher in August compared to other periods of study (Figure 1B). Under the extreme dry conditions encountered in August, the abundance of methanotrophs in the UC was significantly higher than in OA $((P<0.05$, Table 1). Our data showed positive correlations between $p m o A$ gene abundance and soil $\mathrm{NH}_{4}{ }^{+}$content in $\mathrm{OA}$ (Pearson's $r=0.521, P<0.05)$ and in $\mathrm{UC}$ with $\mathrm{NO}_{3}{ }^{-}(r=0.65$, $P<0.01)$ content, i.e., the number of methanotrophs increased with increasing mineral nitrogen content (Figures 1D,E). Moreover, a negative correlation was observed between $p m o A$ gene abundance and $\mathrm{CH}_{4}$ flux $(r=-0.54, P<0.05)$ in the UC and with total nitrogen $(r=-0.52, P<0.05)$ in the OA.

Quantitative PCR with primers q189A/Mb601 targeting Type Ia methanotrophs was the only assay producing PCR products successfully. Other phylogenetic methanotroph groups (MOB amplified in nested PCR with A189/A682/mb661 primers and quantitative PCR with USC $\alpha$, Type Ib, Type II and Methylocella sp. primers) showed only negligible PCR products.

The nos $Z$ gene abundance in the $\mathrm{UC}$ and $\mathrm{OA}$ varied in range from $6 \times 10^{4}$ to $7.3 \times 10^{6}$ nos $Z$ genes $\mathrm{g}^{-1} \mathrm{DW}$ and from $1 \times 10^{5}$ to $1.3 \times 10^{6}$ nos $Z$ genes $\mathrm{g}^{-1} \mathrm{DW}$, respectively (Figure 1C). Under summer drought (August) and stabilized wet conditions in winter (December, SWC around 15\%) the number of nos $Z$ gene abundance increased in the UC more than 18 times compared to other seasons. However, no differences in the nos $Z$ gene abundance between the UC and OA were observed during the study. A negative correlation between nos $Z$ gene abundance, and $\mathrm{N}_{2} \mathrm{O}$ flux $(r=-0.59, P<0.05)$ was observed in the OA site, but not in the UC site.

\section{Soil Enzyme Activities}

Total enzyme activities were significantly higher in the UC area in May and December (Figure 1F). Enzyme activities did not correlate with gene copy numbers or $\mathrm{CH}_{4}$ fluxes, but correlated with $\mathrm{N}_{2} \mathrm{O}$ fluxes. In the UC area, $\mathrm{N}_{2} \mathrm{O}$ flux correlated positively with total enzyme activity $(r=0.60$, $P<0.05)$, with Glucuronidase activity $(r=0.58, P<0.05)$, with Glucosaminidase activity $(r=0.67, P<0.01)$, and with phosphatase activity $(r=0.56, P<0.05)$, whereas in OA site, $\mathrm{N}_{2} \mathrm{O}$ fluxes had a positive correlation with phosphatase activity $(r=0.58, P<0.05)$.

\section{Soil Net $\mathrm{CH}_{4}$ and $\mathrm{N}_{2} \mathrm{O}$ Fluxes}

Results showed that the soil acted mainly as a net sink for $\mathrm{CH}_{4}$, however there were also periods of net $\mathrm{CH}_{4}$ emissions. During the study period $\mathrm{CH}_{4}$ fluxes ranged from -12.3 to $8.6 \mu \mathrm{g} \mathrm{C} \mathrm{m}^{-2}$ $\mathrm{h}^{-1}$. Methane emissions were observed in May in both UC and $\mathrm{OA}$, and in August in the OA only (Table 2). The difference in $\mathrm{CH}_{4}$ flux between areas was highest in October, when the $\mathrm{CH}_{4}$ uptake in the OA was higher than in the UC, and in December, when on the contrary, $\mathrm{CH}_{4}$ uptake in the $\mathrm{OA}$ was lower than in the UC. However, the tree cover had not a general effect on $\mathrm{CH}_{4}$ flux when all time-points were included to the analysis (Mixed-effect model: d.f. $1=1$, d.f. ${ }_{2}=20, P=0.655$ ). Methane fluxes correlated positively with soil temperature both in the $\mathrm{OA}(r=0.75, P<0.01)$, and $\mathrm{UC}$ areas $(r=0.79, P<0.001)$. Methane fluxes also correlated positively with organic matter $(r=0.55, P<0.05)$, CN-ratio $(r=0.57, P<0.05)$ and total carbon $(r=0.67, P<0.01)$ in the UC area. Mean $\mathrm{CH}_{4}$ fluxes, shown as $\mathrm{CO}_{2}$-equivalent fluxes were not different between areas (Table 2).

There was both net uptake and net release of $\mathrm{N}_{2} \mathrm{O}$ occurring and the flux varied from -6.5 to $6 \mu \mathrm{g} \mathrm{N}_{2} \mathrm{O}-\mathrm{N} \mathrm{m}^{-2} \mathrm{~h}^{-1}$ (Table 2). The most pronounced difference between areas was observed in December when the UC had $\mathrm{N}_{2} \mathrm{O}$ release but the OA showed $\mathrm{N}_{2} \mathrm{O}$ uptake. The tree cover had a general effect on $\mathrm{CH}_{4}$ flux when 
TABLE 2 | Soil $\mathrm{CH}_{4}\left(\mu \mathrm{g} \mathrm{CH}_{4}-\mathrm{C} \mathrm{m}^{-2} \mathrm{~h}^{-1}\right)$ and $\mathrm{N}_{2} \mathrm{O}\left(\mu \mathrm{g} \mathrm{N} \mathrm{N}_{2} \mathrm{O}-\mathrm{N} \mathrm{m}^{-2} \mathrm{~h}^{-1}\right)$ fluxes measured at the study site from May to December, 2011.



Carbon dioxide equivalents $\left(\mathrm{CO}_{2}^{\mathrm{eq}}, \mu \mathrm{g} \mathrm{CO} \mathrm{CO}^{\mathrm{eq}} \mathrm{m}^{-2} \mathrm{~h}^{-1}\right)$ were calculated by multiplying the flux with Global Warming Potential in time-horizon of 100 years $\left(\mathrm{CH}_{4}=34\right.$; $\mathrm{N}_{2} \mathrm{O}=298$, Myhre et al., 2013). Values are mean $\pm S E(n=3)$. December, 2011. Statistical significant differences $(P<0.05)$ between OA and UC area is shown with different letters.

all time-points were included in the analysis (Table 2; Mixedeffect model: d.f. $1=1$, d.f. $2=20, P<0.05)$. Nitrous oxide fluxes correlated negatively with nos $Z$ gene abundance $(r=-0.59$, $P<0.05)$ and soil $\mathrm{pH}(r=0.65, P<0.01)$, and positively with soil temperature $(r=0.57, P<0.05)$ in OA. In the UC area, $\mathrm{N}_{2} \mathrm{O}$ fluxes correlated positively with total enzyme activity $(r=0.60$, $P<0.05)$, with glucuronidase activity $(r=0.58, P<0.05)$, with glucosaminidase activity $(r=0.67, P<0.01)$, and with phosphatase activity $(r=0.56, P<0.05)$. In the OA area $\mathrm{N}_{2} \mathrm{O}$ fluxes correlated positively with phosphatase activity $(r=0.58$, $P<0.05)$. $\mathrm{N}_{2} \mathrm{O}$ fluxes in the UC area shown as $\mathrm{CO}_{2}$-equivalents was higher than that in OA area (Table 2).

\section{DISCUSSION}

The cork oak trees had a significant effect on soil properties and subsequent soil EEAs, on the abundance of microbes, and finally on the non- $\mathrm{CO}_{2}$ net $\mathrm{GHG}$ fluxes. In this study soil $\mathrm{CH}_{4}$ uptake was generally activated in autumn when soil moisture was higher and temperature lower than in summer. Trees are known to affect soil $\mathrm{CH}_{4}$ consumption, but whether this is due to tree effects on microbial $\mathrm{CH}_{4}$ oxidation or soil gas diffusivity is not known (Menyailo, 2007; Menyailo et al., 2010). Oak canopy increased soil moisture, which could explain the stronger negative correlation found between methane fluxes and $p m o A$ gene abundance in the UC area compared to the $\mathrm{OA}$ area. It is possible, that the dryness in the OA area limited the activity and growth of methanotrophs. Thus, even at the highest water content, moisture did not limit the activity of methanotrophs indicating good availability of oxygen and methane. SWC and associated gas diffusivity are known to affect abundance and activity of methanotrophs (Borjesson et al., 2004; Einola et al., 2007). However, there is evidence for the presence of anaerobic microsites in the studied soils because net $\mathrm{CH}_{4}$ emissions were also observed, showing that in some moisture and temperature conditions $\mathrm{CH}_{4}$ production (activity of methanogens) exceeded $\mathrm{CH}_{4}$ oxidation (activity of methanotrophs). The net release of $\mathrm{CH}_{4}$ correlated positively with temperature and soil organic matter and carbon indicating that these factors favored methanogens over methanotrophs. However, Type Ia methanotrophs especially in the UC areas had a significant role in reducing of $\mathrm{CH}_{4}$ emissions and in the consumption of atmospheric $\mathrm{CH}_{4}$ since their abundance was affected by seasonal variation and correlated with $\mathrm{CH}_{4}$ efflux. Input of organic carbon by trees in $\mathrm{UC}$ area increased $\mathrm{CH}_{4}$ cycling, and therefore a positive correlation in UC area but not in $\mathrm{OA}$ area can be explained. An increase in organic matter supports the activity of heterotrophic microbes as seen here by the higher enzyme activities in the UC area as compared to the OA area. It is likely that the availability of low molecular weight organic substrates needed for methanogenesis was higher in the UC area resulting from the higher enzyme activities found there. An increase in soil temperature further supported net $\mathrm{CH}_{4}$ release in the present study. This is associated with higher microbial decomposition processes and oxygen consumption at higher temperatures, which can create anaerobic microsites in the clayrich soil. It is noteworthy that $\mathrm{CH}_{4}$ fluxes in the UC and OA areas did not differ much. We would expect higher $\mathrm{CH}_{4}$ production in UC area rather than in OA area. Evidently the higher $\mathrm{CH}_{4}$ oxidation in the UC area discussed above counteracted the possible higher $\mathrm{CH}_{4}$ production there.

Methanotrophs in the study site belonged to Type Ia methanotrophs. Type I methanotrophs are usually found in extreme conditions where competition survival strategy supports their fast response to improved substrate availability (Ho et al., 2013). Moreover, Type I methanotrophs grow in a wide temperature range, from thermophilic (Bodrossy et al., 1997; Tsubota et al., 2005) to psychrophilic (Liebner et al., 2009; Graef et al., 2011) conditions. In this site, soil temperature varied substantially from 12.7 to $27.9^{\circ} \mathrm{C}$, which could favor the occurrence of Type I methanotrophs over the other types. In addition to the temperature related selection, potential internal methane source in the soil as reflected as $\mathrm{CH}_{4}$ emissions, might have selected for presumably low affinity Type I methanotrophs in this site. However, the PCR assay used for USC $(\alpha)$ methanotrophs (Kolb et al., 2003) might not have recognized all high-affinity atmospheric $\mathrm{CH}_{4}$ oxidizers living in this site. These methanotrophs could have been detected more recently generated primer set with broader specifity for $\operatorname{USC}(\alpha)$ (Degelmann et al., 2010).

Nitrous oxide uptake from the atmosphere has been explored in few reports even under dry conditions when gas diffusivity is good (Rosenkranz et al., 2006; Goldberg and Gebauer, 2009). In theory, the dry conditions when oxygen availability is high should not support nitrous oxide reduction (Morley et al., 2008). Rosenkranz et al. (2006) linked negative fluxes in Mediterranean forest soil to very low $\mathrm{N}$ availability and high soil $\mathrm{C}$ content, and considered aerobic denitrification by heterotrophic denitrifiers as a possible pathway for $\mathrm{N}_{2} \mathrm{O}$ uptake. In our soil, higher soil moisture, higher nos $Z$ gene abundance, higher total enzyme activities, and higher $\mathrm{N}_{2} \mathrm{O}$ fluxes (emissions) were concurrent 
within UC area. Mineralization of SOM and exudates from tree roots in the UC area produced more soluble carbon to fuel denitrification. However, nitrate content was similar in both areas. We have no data on nitrification activity and nitrate uptake by plants, which hampers a concise conclusion about the nitrate turnover and availability in soils. In the OA area there was a positive correlation between $\mathrm{N}_{2} \mathrm{O}$ fluxes and nos $Z$ gene abundance in contrast to the UC area. The primer set used for enumeration of nos $Z$ genes did not cover nos $Z$-II genes. However, the typical $\mathrm{N}_{2} \mathrm{O}$ consuming nos $Z$ genes detected in our study had a significant role in $\mathrm{N}_{2} \mathrm{O}$ consumption, since their abundance was correlated with $\mathrm{N}_{2} \mathrm{O}$ flux and affected by seasonal variation. We observed a positive correlation between SOM input in the UC area and catalase activity of four studied enzymes that degrade SOM and provide energy $(\mathrm{C})$ and nutrients $(\mathrm{N}$ and $\mathrm{P}$ ) for ecosystem functioning. These catalases also correlated positively with $\mathrm{N}_{2} \mathrm{O}$ flux in UC area. Since denitrifiers require organic carbon for growth, a correlative link between $\mathrm{N}_{2} \mathrm{O}$ flux and enzyme activities can be explained by their heterotrophic lifestyle.

Moreover, in this study $\mathrm{N}_{2} \mathrm{O}$ uptake was correlated with lower EEA, lower $\mathrm{C}$ and $\mathrm{N}$ supply and lower soil moisture. Positive correlations between $\mathrm{N}_{2} \mathrm{O}$ fluxes and soil enzyme activities, especially in UC area, could be explained by higher SOM input into UC area. However, in the UC area with higher water content and substrate availability for denitrification, more of the produced $\mathrm{N}_{2} \mathrm{O}$ could be reduced to $\mathrm{N}_{2}$ and therefore gene abundance of nos $Z$ did not reflect the overall denitrification. The EEAs are not connected directly to metabolism of nitrous oxide or bacterial denitrification. However, EEAs may provide a clue about the soil microbial activity in general, which is correlated with nitrous oxide fluxes. These correlations need to be evaluated critically since these linkages may be simply coincidental without a real metabolic connection to each other. The impact of trees on soil properties (SWC, SOM, litter fall, root density) and a strong positive correlation between SOM and both $\mathrm{CH}_{4}$ and $\mathrm{N}_{2} \mathrm{O}$ effluxes were previously reported (Shvaleva et al., 2014). The current study was able to link the abundance of methanotrophs with $\mathrm{CH}_{4}$ fluxes in UC area, and the abundance of $\mathrm{N}_{2} \mathrm{O}$ consuming bacteria in $\mathrm{OA}$ area.

Nitrous oxide uptake was detected in $60 \%$ of all studied timepoints. While measuring such small fluxes close to the detection limit of the gas chromatograph used, it is important to evaluate if the equipment is sensitive enough to detect $\mathrm{N}_{2} \mathrm{O}$ uptake. The GC and detectors used were accurate enough to measure such small $\mathrm{N}_{2} \mathrm{O}$ fluxes. Most of measured $\mathrm{N}_{2} \mathrm{O}$ fluxes were above minimum detectable flux. However, the measurements performed for non$\mathrm{CO}_{2}$ GHG fluxes didn't cover whole ecosystem GHG fluxes including processes in the phyllosphere. The tree stand itself contributes to the $\mathrm{GHG}$ balance by $\mathrm{CO}_{2}$ sequestration through photosynthesis. In addition, trees are a transpiration channel from soil to atmosphere and it has been shown that plants are capable of $\mathrm{CH}_{4}$ emissions (Keppler et al., 2006; Carmichael et al., 2014) and in some circumstances $\mathrm{CH}_{4}$ uptake is possible by plants (Sundqvist et al., 2012). Moreover, $\mathrm{N}_{2} \mathrm{O}$ emissions from plants were reported recently, with a rate comparable with soil $\mathrm{N}_{2} \mathrm{O}$ emissions, by ammonia oxidizing bacteria on leaf surfaces (Bowatte et al., 2015). Therefore our measured soilrelated non- $\mathrm{CO}_{2}$ GHG balances between $\mathrm{UC}$ and $\mathrm{OA}$ areas might be underestimated, and we can't be completely certain of the total balance of all GHG produced and consumed in these sites. Similar non- $\mathrm{CO}_{2}$ GHG balances were also earlier examined in this same study-site (Shvaleva et al., 2014). However, earlier in another montado site higher $\mathrm{CH}_{4}$ uptake compensated $\mathrm{N}_{2} \mathrm{O}$ emission, which kept non- $\mathrm{CO}_{2}$ balance negative (Shvaleva et al., 2011). This emphasizes spatial and seasonal variation of GHG effluxes in montado ecosystems. However, if future climatic conditions support tree decline, soil related nitrous oxide emissions might be reduced from Mediterranean montado ecosystems, provided that understory vegetation and soil conditions remain similar to OA area.

\section{CONCLUSION}

Oak tree cover had an effect on soil properties, soil enzymatic activities, and the abundance of $\mathrm{CH}_{4}$ and $\mathrm{N}_{2} \mathrm{O}$ metabolizing bacteria and as a consequence, on $\mathrm{CH}_{4}$ and $\mathrm{N}_{2} \mathrm{O}$ fluxes. Correlation between soil-atmosphere $\mathrm{CH}_{4}$ exchange and abundance of Type I pmoA genes under tree canopies, and correlation between $\mathrm{N}_{2} \mathrm{O}$ exchange and abundance of nos $Z$ genes in OAs suggests that these microbial groups may contribute to most of the gasses consumed in evergreen oak woodlands. Oak trees exert these effects on a functional group of soil micro-organisms through the complex interactions between plants, microorganisms, and soil characteristics (SWC, SOM, root density, litter fall, and enzyme activities). Our results suggest that oak tree vegetation does not change mean soil $\mathrm{CH}_{4}$ uptake, but significantly increases mean $\mathrm{N}_{2} \mathrm{O}$ fluxes and this neutralizes the soil non- $\mathrm{CO}_{2}$ uptake in Mediterranean oak forests, and it can even turn the soil non- $\mathrm{CO}_{2}$ GHG balance from negative to positive when compared to non-oak tree vegetated surfaces.

\section{ACKNOWLEDGMENTS}

The authors acknowledge the financial support of FCT (Fundação para a Ciência e Tecnologia), through the project In-Nitro PTDC/BIA-ECS/122214/2010 and through post doctoral fellowship to AS (SFRH/BPD/43643/2008), FCS (SFRH/BPD/46839/2008), DF (SFRH/BPD/84229/2012). $\mathrm{HS}$ and $\mathrm{PM}$ are acknowledging Finnish Academy (No. 258875). Joaquim Miguel Costa, MA and Ute Skiba are acknowledged for their contribution on data production and their comments on manuscript.

\section{SUPPLEMENTARY MATERIAL}

The Supplementary Material for this article can be found online at: http://journal.frontiersin.org/article/10.3389/fmicb. 2015.01104 


\section{REFERENCES}

Abell, G. C. J., Stralis-Pavese, N., Sessitsch, A., and Bodrossy, L. (2009). Grazing affect methanotroph activity and diversity in an alpine meadow soil. Environ. Microbiol. Rep. 1, 457-465. doi: 10.1111/j.1758-2229.2009.0 0078. $\mathrm{x}$

AFN (2010). Relatório do 50. Inventário Florestal Nacional (IFN5). Lisboa: Autoridade Florestal Nacional.

Allison, S. D., and Treseder, K. K. (2008). Warming add drying suppress microbial activity and carbon cycling in boreal forest soils. Glob. Chang. Biol. 14, 28982909. doi: 10.1111/j.1365-2486.2008.01716.x

Bardgett, R. D., Streeter, T. C., Cole, L., and Hartley, I. R. (2002). Linkages between soil biota, nitrogen availability, and plant nitrogen uptake in a mountain ecosystem in the Scottish Highlands. Appl. Soil Ecol. 19, 121-134. doi: 10.1016/S0929-1393(01)00188-3

Bartossek, R., Nicol, G. W., Lanzen, A., Klenk, H. P., and Schleper, C. (2010). Homologues of nitrite reductases in ammonia- oxidizing archaea: diversity and genomic context. Environ. Microbiol. 12, 1075-1088. doi: 10.1111/j.14622920.2010.02153.x

Bender, M., and Conrad, R. (1995). Effect of $\mathrm{CH}_{4}$ concentrations and soil conditions on the induction of $\mathrm{CH}_{4}$ oxidation activity. Soil Biol. Biochem. 27, 1517-1527. doi: 10.1016/0038-0717(95)0 0104-M

Betlach, M. R., and Tiedje, J. M. (1981). Kinetic explanation for accumulation of nitrite, nitric oxide, and nitrous oxide during bacterial denitrification. Appl. Environ. Microbiol. 42, 1074-1084.

Bodelier, P. L. E., Roslev, P., Henckel, T., and Frenzel, P. (2000). Stimulation by ammonium-based fertilizers of methane oxidation in soil around rice roots. Nature 403, 421-424. doi: 10.1038/35000193

Bodrossy, L., Holmes, E. M., Holmes, A. J., Kovács, K. L., and Murrell, J. C. (1997). Analysis of $16 \mathrm{~S}$ rRNA and methane monooxygenase gene sequences reveals a novel group of thermotolerant and thermophilic methanotrophs, Methylocaldum gen. nov. Arch. Microbiol. 168, 493-503. doi: $10.1007 / \mathrm{s} 002030050527$

Borjesson, G., Sundh, I., and Svensson, B. H. (2004). Microbial oxidation of $\mathrm{CH}_{4}$ at different temperatures in landfill cover soils. FEMS Microbiol. Ecol. 48, 305-312. doi: 10.1016/j.femsec.2004.02.006

Bowatte, S., Newton, P. C. D., Brock, S., Theobald, P., and Luo, D. (2015). Bacteria on leaves: a previously unrecognised source of $\mathrm{N}_{2} \mathrm{O}$ in grazed pastures. ISME J. 9, 265-267. doi: 10.1038/ismej.2014.118

Braker, G., and Conrad, R. (2011). Diversity, structure, and size of $\mathrm{N}_{2} \mathrm{O}$ producing microbial communities in soils - What matters for their functioning? Adv. Appl. Microb. 75, 33-70. doi: 10.1016/B978-0-12-387046-9.0 0002-5

Burns, R. G., and Dick, R. P. (2002). Enzymes in the Environment: Activity, Ecology and Applications. New York, NY: Marcel Dekker.

Butterbach-Bahl, K., and Papen, H. (2002). Four years continuous record of $\mathrm{CH}_{4}$ exchange between the atmosphere and untreated and limed soil of a N-saturated spruce and beech forest ecosystem in Germany. Plant Soil 240, 77-90. doi: 10.1023/A:1015856617553

Carmichael, M. J., Bernhardt, E. S., Bräuer, S. L., and Smith, W. K. (2014). The role of vegetation in methane flux to the atmosphere: should vegetation be included as a distinct category in the global methane budget? Biogeochemistry 119, 1-24. doi: 10.1007/s10533-014-9974-1

Carreira, J. A., and Lajtha, K. L. (1997). Factors affecting phosphate sorption along a Mediterranean dolomitic soils and vegetation chronosequence. Eur. J. Soil Sci. 48, 139-149. doi: 10.1111/j.1365-2389.1997.tb00193.x

Castaldi, S., Costantini, M., Cenciarelli, P., Ciccioli, P., and Valentini, R. (2007). The methane sink associated to soils of natural and agricultural ecosystems in Italy. Chemosphere 66, 723-729. doi: 10.1016/j.chemosphere.2006. 07.089

Castaldi, S., and Fierro, A. (2005). Soil-atmosphere methane exchange in undisturbed and burned Mediterranean shrubland of southern Italy. Ecosystems 8, 182-190. doi: 10.1007/s10021-004-0093-z

Degelmann, D. M., Borken, W., Drake, H. L., and Kolb, S. (2010). Different atmospheric methane-oxidizing communities in European beech and Norway spruce soils. Appl. Environ. Microbiol. 76, 3228-3235. doi: 10.1128/AEM.02730-09
Einola, J. K. M., Kettunen, R. H., and Rintala, J. A. (2007). Responses of methane oxidation to temperature and water content in cover soil of a boreal landfill. Soil Biol. Biochem. 39, 1156-1164. doi: 10.1016/j.soilbio.2006.12.022

Fangueiro, D., Bol, R., and Chadwick, D. (2008). Assessment of the potential $\mathrm{N}$ mineralization of six particle size fractions of two different cattle slurries. J. Plant Nutr. Soil Sci. 171, 313-315. doi: 10.1002/jpln.20070 0226

Fierer, N., Schimel, J. P., and Holden, P. A. (2003). Influence of drying-rewetting frequency on soil bacterial community structure. Microb. Ecol. 45, 63-71. doi: 10.1007/s00248-002-1007-2

Garcia-Herrera, R., Paredes, D., Trigo, R. M., Hernandez, E., Barriopedro, D., and Mendes, M. A. (2007). The outstanding 2004/05 drought in the Iberian Peninsula: associated atmospheric circulation. J. Hydrometerol. 8, 483-498. doi: 10.1175/JHM578.1

Goldberg, S. D., and Gebauer, G. (2009). Drought turns a central European Norway spruce forest soil and $\mathrm{N}_{2} \mathrm{O}$ source to a transient $\mathrm{N}_{2} \mathrm{O}$ sink. Glob. Change Biol. 15, 850-860. doi: 10.1111/j.1365-2486.2008.01752.x

Gordon, H., Haygarth, P. M., and Bardgett, R. D. (2008). Drying and rewetting effects on soil microbial community composition and nutrient leaching. Soil Biol. Biochem. 40, 302-311. doi: 10.1016/j.soilbio.2007.08.008

Graef, C., Hestnes, A. G., Svenning, M. M., and Frenzel, P. (2011). The active methanotrophic community in a wetland from the High Artic. Environ. Microbiol. Rep. 4, 466-472. doi: 10.1111/j.1758-2229.2010.0 0237.x

Griffiths, R. I., Whiteley, A. S., O’Donnell, A. G., and Bailey, M. J. (2000). Rapid method for coextraction of DNA and RNA from natural environments for analysis of ribosomal DNA and rRNA-based microbial community composition. Appl. Environ. Microb. 66, 5488-5491. doi: 10.1128/AEM.66.12.5488-5491.2000

Hanson, R. S., and Hanson, T. E. (1996). Methanotrophic bacteria. Microbiol. Rev. 60, 439-471.

Henry, S., Bru, D., Stres, B., Hallet, S., and Philippot, L. (2006). Quantitative detection of the nosZ Gene, encoding nitrous oxide reductase, and comparison of the abundances of 16S rRNA, narG, nirK, and nosZ genes in soils. Appl. Environ. Microb. 72, 5181-5189.

Ho, A., Kerckhof, F. M., Lüke, C., Reim, A., Krause, S., Boon, N., et al. (2013). Conceptualizing functional traits and ecological characteristics of methaneoxidizing bacteria as life strategies. Environ. Microbiol. Rep. 5, 335-345. doi: 10.1111/j.1758-2229.2012.00370.x

Horn, M. A., Drake, H. L., and Schramm, A. (2006). Nitrous oxide reductase genes (nosZ) of denitrifying microbial populations in soil and the earthworm gut are phylogenetically similar. Appl. Environ. Microbiol. 72, 1019-1026. doi: 10.1128/AEM.72.2.1019-1026.2006

Horneck, D. A., and Miller, R. O. (1998). "Determination of total nitrogen in plant tissue," in Handbook of Reference Methods for Plant Analysis, ed. P. Karla (Boca Raton, FL: CRC Press), 75-83.

Islam, T., Jensen, S., Reigstad, L. J., Larsen, O., and Birkeland, N. K. (2008). Methane oxidation at $55^{\circ} \mathrm{C}$ and $\mathrm{pH} 2$ by a thermoacidophhhilic bacterium belonging to the Verrucomicrobia phylum. Proc. Natl. Acad. Sci. U.S.A. 105, 300-304. doi: 10.1073/pnas.0704162105

Jensen, K. D., Beier, C., Michelsen, A., and Emmett, B. A. (2003). Effects of experimental drought on microbial processes in two temperate heathlands at contrasting water conditions. Appl. Soil Ecol. 24, 165-176. doi: 10.1016/S09291393(03)00091-X

Jones, C. M., Graf, D. R., Bru, D., Philippot, L., and Hallin, S. (2013). The unaccounted yet abundant nitrous oxide-reducing microbial community: a potential nitrous oxide sink. ISME J. 7, 417-426. doi: 10.1038/ismej.2012.125

Jones, C. M., Spor, A., Brennan, F. P., Breuil, M.-C., Bru, D., Lemanceau, P., et al. (2014). Recently identified microbial guild mediates soil $\mathrm{N}_{2} \mathrm{O}$ sink capacity. Nat. Clim. Change 4, 801-805. doi: 10.1038/nclimate2301

Kardol, P., Reynolds, W. N., Norby, R. J., and Classen, A. T. (2011). Climate change effects on soil microarthropod abundance and community structure. Appl. Soil Ecol. 47, 37-44. doi: 10.1016/j.apsoil.2010.11.001

Keppler, F., Hamilton, J. T. G., Braß, M., and Röckmann, T. (2006). Methane emissions from terrestrial plants under aerobic conditions. Nature 439, $187-$ 191. doi: 10.1038/nature04420

Kim, S.-W., Fushinobu, S., Zhou, S., Wakagi, T., and Shoun, H. (2009). Eukaryotic nirK genes encoding copper-containing nitrite reductase: originating from 
the protomitochondrion? Appl. Environ. Microbiol. 75, 2652-2658. doi: 10.1128/AEM.02536-08

Knief, C. A., Kolb, S., Bodelier, P. L. E., Lipski, A., and Dunfield, P. F. (2006). The activity methanotrophic community in hydromorphic soils changes in response to changing methane concentration. Environ. Microbiol. 8, 321-333. doi: 10.1111/j.1462-2920.2005.00898.x

Kolb, S. (2009). The quest for atmospheric methane oxidizers in forest soils. Environ. Microbiol. Rep. 1, 336-346. doi: 10.1111/j.1758-2229.2009. 00047.x

Kolb, S., Knief, C., Stubner, S., and Conrad, R. (2003). Quantitative detection of methanotrophs in soil by novel pmoA-targeted real-time PCR assay. Appl. Environ. Microb. 69, 2423-2429. doi: 10.1128/AEM.69.5.2423-242 9.2003

Lau, E., Ahmad, A., Steudler, P. A., and Cavanaugh, C. M. (2007). Molecular characterization of methanotrophic communities in forest soils that consume atmospheric methane. FEMS Microbiol. Ecol. 60, 490-500. doi: 10.1111/j.15746941.2007.00308.x

Liebner, S., Rublack, K., Stuehrmann, T., and Wagner, D. (2009). Diversity of aerobic methanotrophic bacteria in a permafrost active layer soil of the Lena Delta. Siberia. Microb. Ecol. 57, 25-35. doi: 10.1007/s00248-008-9411-x

Lionello, P. (2007). Precipitation in the Mediterranean Region: present trends and climate change. Geophys. Res. Abstr. 9, 096692.

McDonald, I. R., Bodrossy, L., Chen, Y., and Murrell, J. C. (2008). Molecular ecology techniques for the study of aerobic methanotrophs. Appl. Environ. Microbiol. 65, 83-103.

Meehl, G. A., and Tebaldi, C. (2004). More intense, more frequent and longer lasting heat waves in the 21 st century. Science 305, 994-997. doi: 10.1126/science.1098704

Menyailo, O. V. (2007). The influence of tree species on the biomass of denitridying bacteria in gray forest soils. Eurasian Soil Sci. 3, 302-307. doi: $10.1134 /$ S1064229307030088

Menyailo, O. V., Abraham, W.-R., and Conrad, R. (2010). Tree species affect atmospheric $\mathrm{CH}_{4}$ oxidation without altering community composition of soil methanotrophs. Soil Biol. Biochem. 42, 101-107. doi: 10.1016/j.soilbio.2009.10.005

Mohanty, S. R., Bodelier, P. L. E., and Conrad, R. (2007). Effect of temperature on composition of the methanotrophic community in rice field and forest soil. FEMS Microbiol. Ecol. 62, 24-31. doi: 10.1111/j.1574-6941.2007. 00370.x

Morley, N., Baggs, E. M., Dörsch, P., and Bakken, L. (2008). Production of $\mathrm{NO}, \mathrm{N}_{2} \mathrm{O}$ and $\mathrm{N}_{2}$ by extracted soil bacteria, regulation by $\mathrm{NO}_{2}$ - and $\mathrm{O}_{2}$ concentrations. FEMS Microbiol. Ecol. 65, 102-112. doi: 10.1111/j.15746941.2008.00495.x

Myhre, G. D., Shindell, F.-M., Bréon, W., Collins, J., Fuglestvedt, J., Huang, J., et al. (2013). "Anthropogenic and natural radiative forcing," in Climate Change 2013: The Physical Science Basis. Contribution of Working Group I to the Fifth Assessment Report of the Intergovernmental Panel on Climate Change, eds T. F. Stocker, D. Qin, G.-K. Plattner, M. Tignor, S. K. Allen, J. Boschung, et al. (Cambridge: Cambridge University Press).

Nelson, E. W., and Sommers, L. E. (1996). "Total carbon, organic carbon, and organic matter," in Methods of Soil Analysis: Chemical Methods, Part 3, ed. D. L. Sparks (Madison, WI: Soil Science Society of America).

Nermani, P. R., Keeling, C. D., Hashimoto, H., Jolly, W. M., Piper, S. C., Tucker, C. J., et al. (2003). Climate-driven increases in global terrestrial net primary production from 1982 to 1999 . Science 300, 1560-1563.

Pol, A., Heijmans, K., Harhangi, H. R., Tedesco, D., Jetten, M. S. M., and Op den Camp, H. J. M. (2007). Methanotrophy below pH 1 by a new Verrucomicrobia species. Nature 450, 874-878. doi: 10.1038/nature 06222

Pritsch, K., Courty, P. E., Churin, J. L., Cloutier-Hurteau, B., Ali, M. A., Damon, C., et al. (2011). Optimized assay and storage conditions for enzyme activity profiling of ectomycorrhizae. Mycorrhiza 21, 589-600. doi: 10.1007/s00572011-0364-4

R Core Team (2013). R: A Language and Environment for Statistical Computing. Vienna: R Foundation for Statistical Computing. Available at: http://www. R-project.org/

Rich, J. J., Heichen, R. S., Bottomley, P. J., Cromack, K., and Myrold, D. D. (2003). Community composition and functioning of denitrifying bacteria from adjacent meadow and forest soils. Appl. Environ. Microbiol. 69, 5974-5982. doi: 10.1128/AEM.69.10.5974-5982.2003

Rosenkranz, P., Bruggemann, N., Papen, H., Xu, Z., Seufer, G., and Butterbach-Bahl, K. (2006). $\mathrm{N}_{2} \mathrm{O}, \mathrm{NO}$ and $\mathrm{CH}_{4}$ exchange and microbial $\mathrm{N}$ turnover over a Mediterranean pine forest soil. Biogeosciences 3, 121-133.

Sanford, R. A., Wagner, D. D., Wu, Q., Chee-Sanford, J. C., Thomas, S. H., CruzGarcía, C., et al. (2012). Unexpected nondenitrifier nitrous oxide reductase gene diversity and abundance in soils. Proc. Natl. Acad. Sci. U.S.A. 109, 19709-19714. doi: $10.1073 /$ pnas.1211238109

Sardans, J., and Penuelas, J. (2012). The role of plants in the effects of global change on nutrient availability and stoichiometry in plant-soil system. Plant Physiol. 160, 1741-1761. doi: 10.1104/pp.112.208785

Schmidt, I. K., Tietema, A., Williams, D., Gundersen, P., Beier, C., Emmett, B. A., et al. (2004). Soil solution chemistry and element fluxes in three European heathlands and their responses to warming and drought. Ecosystems 7, 638-649. doi: 10.1007/s10021-004-0217-5

Shoun, H., Kim, D. H., Uchiyama, H., and Sugiyama, J. (1992). Denitrification by fungi. FEMS Microbiol. Lett. 73, 277-281. doi: 10.1111/j.1574-6968.1992.tb05331.x

Shrestha, P. M., Kamman, C., Lenhart, K., Dam, B., and Liesack, W. (2012). Linking activity, composition and seasonal dynamics of atmospheric methane oxidizers in a meadow soil. ISME J. 6, 1115-1126. doi: 10.1038/ismej. 2011.179

Shvaleva, A., Costa e Silva, F., Costa, J. M., Correia, A., Anderson, M., Lobo-do-Vale, R., et al. (2014). Comparison of methane, nitrous oxide fluxes and $\mathrm{CO}_{2}$ respiration rates from a Mediterranean cork oak ecosystem and improved pasture. Plant Soil 374, 883-898. doi: 10.1007/s11104-0131923-6

Shvaleva, A., Lobo-do-Vale, R., Cruz, C., Castaldi, S., Rosa, A. P., Chaves, M. M., et al. (2011). Soil atmosphere greenhouse gases $\left(\mathrm{CO}_{2}, \mathrm{CH}_{4}\right.$ and $\left.\mathrm{N}_{2} \mathrm{O}\right)$ exchange in evergreen oak woodland in southern Portugal. Plant Soil Environ. 57, 471-477.

Siljanen, H. M. P., Saari, A., Bodrossy, L., and Martikainen, P. (2012). Seasonal variation in the function and diversity of methanotrophs in the littoral wetland of a boreal eutrophic lake. FEMS Microbiol. Ecol. 80, 548-555. doi: 10.1111/j.1574-6941.2012.01321.x

Siljanen, H. M. P., Saari, A., Krause, S., Lensu, A., Abell, G. C. J., Bodrossy, L., et al. (2011). Hydrology is reflected in the functioning and community of methanotrophs in the littoral wetland of a boreal lake. FEMS Microbiol. Ecol. 75, 430-445. doi: 10.1111/j.1574-6941.2010.01015.X

Skiba, U., Drewer, J., Tang, Y. S., van Dijk, N., Helfter, C., Nemitz, E., et al. (2009). Biosphere-atmosphere exchange of reactive nitrogen and greenhouse gases at the NitroEurope core flux measurement sites: measurement strategy and first data sets. Agric. Ecosyst. Environ. 133, 139-149. doi: 10.1016/j.agee.2009. 05.018

Smith, M. S., and Tiedje, J. M. (1979). Phases of denitrification following oxygen depletion in soil. Soil Biol. Biochem. 11, 261-267. doi: 10.1016/00380717(79)90071-3

Stieglmaier, M., Mooshammer, M., Kitzler, B., Wanek, W., ZechmeisterBoltenstern, S., Richter, A., et al. (2014). Aerobic nitrous oxide production through $\mathrm{N}$-nitrosating hybrid formation in ammonia-oxidizing archaea. ISME J. 8, 1135-1146. doi: 10.1038/ismej.2013.220

Sundqvist, E., Crill, P., Mölder, M., Vestin, P., and Lindroth, A. (2012). Atmospheric methane removal by boreal plants. Geophys. Res. Lett. 39:L21806. doi: 10.1029/2012GL053592

Theisen, A. R., All, M. H., Radajewski, S., Duwont, M. G., Dunfield, P. F., McDonald, I. R., et al. (2005). Regulation of methane oxidation in the facultative methanotroph Methylocella silvestris BL2. Mol. Microbiol. 58, 682-692. doi: 10.1111/j.1365-2958.2005.04861.x

Thomson, A. J., Giannopoulos, G., Pretty, J., Baggs, E. M., and Richardson, D. J. (2012). Biological sources and sinks of nitrous oxide and strategies to mitigate emissions. Philos. Trans. R. Soc. B 367, 1157-1168.

Tsubota, J., Eshinimaev, B. T., Khmelenina, V. H., and Trotsenko, Y. A. (2005). Methylothermus thermalis gen. nov., sp. nov., a novel moderately thermophilic obligate methanotroph from a hotspring in Japan. Int. J. Syst. Evol. Microbiol. 55, 1877-1884. doi: 10.1099/ijs.0.63691-0 
Vorobév, A. V., Baani, M., Doronina, N. V., Brady, A. L., Liesack, W., Dunfield, P. F., et al. (2011). Methyloferula stellata gen nov., sp. nov., an acidophilic, obligately methanotrophum bacterium possessing only a soluble methane monooxygenase. Int. J. Syst. Evol. Microbiol. 61, 2456-2463. doi: 10.1099/ijs.0.028118-0

Walker, C. B., de la Torre, J. R., Klotz, M. G., Urakawa, H., Pinel, N., Arp, D. J., et al. (2010). Nitrosopumilus maritimus genome reveals unique mechanisms for nitrification and autotrophy in globally distributed marine crenarchaea. Proc. Natl. Acad. Sci. U.S.A. 107, 8818-8823. doi: 10.1073/pnas.0913533107

Weslien, P., Klemedtsson, A. K., and Klemedtsson, L. (2009). Strong pH influence on $\mathrm{N}_{2} \mathrm{O}$ and $\mathrm{CH}_{4}$ fluxes from forested organic soils. Eur. J. Soil Sci. 60, 311-320. doi: $10.1111 / j .1365-2389.2009 .01123 . x$
Conflict of Interest Statement: The authors declare that the research was conducted in the absence of any commercial or financial relationships that could be construed as a potential conflict of interest.

Copyright (c) 2015 Shvaleva, Siljanen, Correia, Costa e Silva, Lamprecht, Lobo-doVale, Bicho, Fangueiro, Anderson, Pereira, Chaves, Cruz and Martikainen. This is an open-access article distributed under the terms of the Creative Commons Attribution License (CC BY). The use, distribution or reproduction in other forums is permitted, provided the original author(s) or licensor are credited and that the original publication in this journal is cited, in accordance with accepted academic practice. No use, distribution or reproduction is permitted which does not comply with these terms. 